Vol. 8, Issue 11, November 2021

DOI: $10.17148 /$ IARJSET.2021.81116

\title{
Implementation of Different Current Commutation in Matrix Converter
}

\author{
Mr. Prabhat Kumar'1, Dr.Shafali Jain ${ }^{2}$, Mrs. Veerinder Kaur ${ }^{3}$ \\ ${ }^{1}$ PG- Power Electronics, Truba College of Science and Technology, Bhopal, M.P \\ ${ }^{2}$ Professor\& Head, Dept of Electrical \& Electronics Engg, TIEIT, Bhopal, M.P \\ ${ }^{3}$ Assistant Professor, Dept of Electrical \& Electronics Engg, TCST, Bhopal, M.P
}

\begin{abstract}
Matrix converter is emerging to be an alternative topology for power converters, drive by persistent cost reduction of silicon devices and the development of reverse blocking IGBTs. One of the major obstacles towards commercial acceptance of this topology has been the commutation of the bi directional switches. A detailed study has been made here to understand the limitations and possible improvement of the existing current commutation techniques in this paper. A universal and synchronous commutation scheme for all the IGBTs is advised so that commutation can smoothly take place as and when required within the minimum possible time depending on the switching time of the IGBT used. The different aspects of this commutation are verified through MATLB simulink. Possibility of step less current commutation is explored.
\end{abstract}

Keywords: matrix converter, commutation, voltage commutation, current commutation, single step, step less commutation, commutation.

\section{INTRODUCTION}

Power frequency changer is essential for converting power from one frequency to another. Earlier, rotary frequency changers where used for converting the utility AC power to the desired frequency AC at the consumer end[1]. Rotary frequency changers consists of motor generator arrangements where the target frequency and magnitude at the load was achieved via subsequent stages of electrical to mechanical to electrical energy conversions as shown in Fig. 1. For example, the utility power can be used to drive an AC motor - this motor will act as a prime mover for a DC generator, which is again used to power a DC motor (whose rotational frequency can be adjusted with that of the target by suitably using the motor parameters). This DC motor may be further used to drive a AC generator whose synchronous speed is dictated by the motor preceding it and from here the power which is now having the desired frequency is fed to the consumer end.

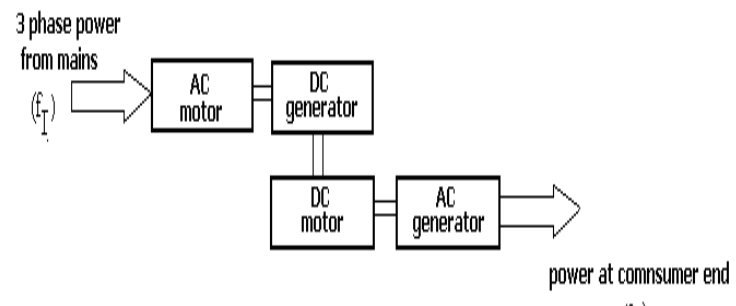

$\left(f_{0}\right)$

Fig. 1.Schematic for rotary power conversion

The efficiency of the entire scheme is a product of the individual efficiencies of the rotating machines involved. For instance, if the efficiency of each rotary machine is as high as $90 \%$ then the overall system has an efficiency of 65.61 $\%$ - which is quite low in terms of energy efficiency. Furthermore, the motor generator combinations make the entire setup quite voluminous. All this necessitated adoption of a different technique to achieve power frequency changing.

Matrix converter is an array of bi-directional switches that directly connects source to a load [2]. A 3-phase to 3-phase matrix converter consists of a matrix of $3 \times 3$ bi-directional switches arranged so that any of the output lines of the converter can be connected to any of the input lines as shown in Fig. 2. 
Vol. 8, Issue 11, November 2021

DOI: 10.17148/IARJSET.2021.81116

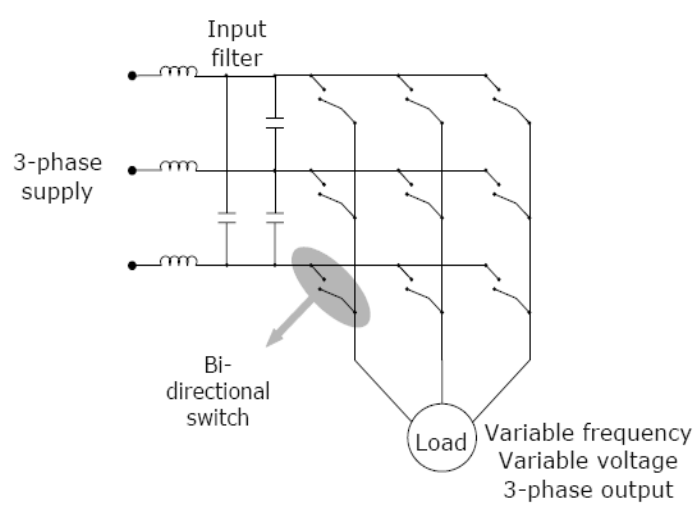

Figure $2.3 \times 3$ matrix converters

The matrix converter offers an almost all silicon solution for AC to AC power conversion. It offers the most desirable features in power frequency changers like

(i)Simple and compact power circuit due to the absence of any large energy storage elements.

(ii)Generation of load voltage with arbitrary amplitude and frequency

(iii)Sinusoidal input and output currents

(iv)Control over input power factor irrespective of load

(v)bi-directional power flow

A 3 phase to 3 phase matrix converter with nine controlled bi-directional switches uses the topology as shown in Fig. 1 and has been used as a replacement for the traditional rectifier-inverter topology. A line filter is included at the input side to block the high frequency component of the input current arising out of switching to enter the utility supply.

\section{DIFFERENT COMMUTATION TECHNIQUES}

A study was carried out to find the safe, fast and easily realizable commutation strategy. IGBT is taken as the switching device. Different schemes are in use for commutation [4]. The schemes follow the switching constraints and also take into account the finite switching times of the semiconductor devices and sensor delays. Some of these rely on the output current direction, while others rely on relative magnitudes of input voltages to activate the commutation stages. However, the disadvantages of relative voltage based commutation method outweighs its advantages as has been pointed out in [6] where the commutation time has been shown to be greater than the methods relying on output current directions. The main disadvantage of output current detection based commutation is that the offset errors make erroneous signals for commutation logic for which output may be open circuited causing over voltage. However, this is of no major concern because of a clamp circuit connected between the input and output terminals [2] can be used to effectively counter this problem. The over voltages can appear from the input side, originated by line voltage perturbations. Also, dangerous over voltages can appear from the output side, caused by an over current fault. When the switches are turned off following an over current fault, the current in the inductive load is suddenly interrupted. The energy stored in the motor inductance has to be discharged without creating dangerous over voltages. A clamp circuit, as shown in Fig.3, is the most common solution to avoid the over voltages coming from the grid and from the motor. This clamp configuration uses 12 fast- recovery diodes to connect the capacitor to the input and output terminals.

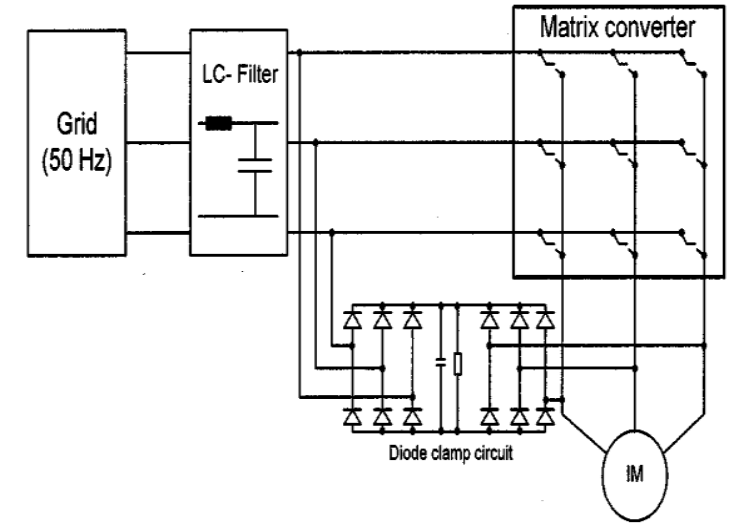

Fig. 3. Matrix converter with clamp circuit 
Therefore, the method using output current direction information has been considered here for further improvement in commutation time. The output current direction can be sensed by using either output current sensors or by measuring the voltages across each device in a bi-directional switch cells which was proposed and had been covered in details in [7]. The process allows the current to commutate from one switch to another without causing a line-to-line short circuit or a load to be open circuited. This commutation is known as "semi-soft" commutation since $50 \%$ of the switching is by devices that are reverse biased. This implementation is asynchronous. In this method data transfer is not based on predetermined timing pattern and is limited by frequent interactions between the sensor circuits during the commutation process. This adds unwanted delays of the sensing devices to the commutation process. The total time taken by the commutation process cannot be estimated quantitatively. A large number of sensing circuitry (one voltage sensor per IGBT device) has to be used to implement the method. The sensors need to interact in between themselves as well as the gate driver during the commutation process. This makes the control scheme complicated and offsets the other advantages of two-step commutation using voltage measurements across the switching devices.

In this report, a generalized, synchronous switching logic for current commutation based on output current direction [8] is considered for detail study and further improvement. The advantages of this schemes are (1) entire process of commutation is a synchronous one, (2) is not affected by delays from current sensor circuits and (3) commutation time can be conveniently estimated and fixed for any commutation requirement occurring any time and anywhere in the circuit. This time is also programmable depending on the switching times of the semiconductor devices. The commutation time used here $(1.6 \mu \mathrm{s})$ for four-step commutation considering a particular type of IGBTs [9]. This is negligible compared to the sampling period of pulse width modulation of $20 \mathrm{KHz}(1.6 \mu \mathrm{s}<<50 \mu \mathrm{s})$. However, for subintervals of the duty cycles, this commutation time may be significant. But this limit should be adhered to for safe commutation. The commutation sub-intervals are general and hence, are applicable for all switching devices including IGBTs. The commutation process is described in the following section.

\section{GENERALIZED SYNCHRONOUS CURRENT DIRECTION BASED COMMUTATION METHOD}

The commutation scheme is explained with the help of a two-phase to single phase matrix converter. The schematic of the converter was shown in the section is shown in Fig.4. The two phase to single phase matrix converter is considered to make the analysis simple but rigorous. The two ac voltage sources of same magnitude and phase but with phase differences are the two input supply phases to the matrix converter. Two bi-directional switch cells connect those two phases to the single phase load. The switch cells are composed of two emitter-coupled back to back IGBTs with inverse parallel connected diodes. The modulation pulses for these switches obeys the constrains of switching i.e. at any instant of time either of the switch cells must get switch -on gating pulse when the other receives switch-off gating pulse.

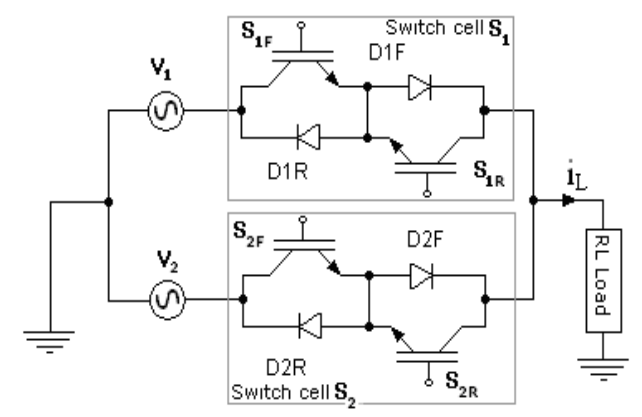

Fig. 4: Two phase to single phase matrix converter considered in the scheme.

\section{Four step commutation:}

We consider the circuit shown in Fig.4. It is assumed that at the instant of time considered, the load current (i $\left.\mathbf{i}_{\mathrm{L}}\right)$ is in the direction shown and that the upper bi-directional switch $\mathrm{S} 1$ is closed i.e. active. When a commutation to $\mathrm{S} 2$ is required, the current direction is used to determine which device in the active cell is not conducting. This device (in this case, $\mathrm{S} 1 \mathrm{R})$ is then turned off first. The device that will conduct the current

in the incoming switch is then gated (S2F in this example) after a time duration $t_{C 1}$. The load current begins to divert to the incoming device. The outgoing device $(\mathrm{S} 1 \mathrm{~F})$ is turned off just after the incoming device $\mathrm{S} 2 \mathrm{~F}$ (time interval $\left.t_{C 2}\right)$ starts sharing the load current. The load current is completely transferred to the incoming device after certain time depending on the incoming voltage and circuit parameters. The remaining device in the incoming switch (S2R) is turned on after time duration $t_{C 3}$ assuming the outgoing device will turn-off completely after this time interval. This 
DOI: $10.17148 /$ IARJSET.2021.81116

will allow current reversals in steady state. This precaution is taken to prevent input short circuit. The process is illustrated by the timing diagram as shown in Fig.5

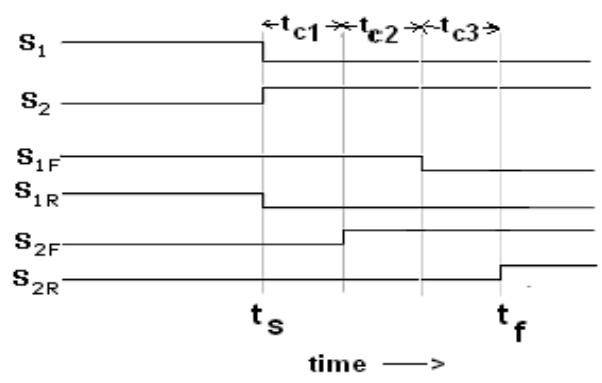

Fig. 5 :- Four step current commutation

\section{Three step commutation:}

In the case of a three step commutation method, $S_{2 F}$ and $S_{1 F}$ has to be turned on and off at the same instant. The corresponding timing diagram is shown in the Fig.6. Since turn off time of an IGBT is greater than the turn on time under all operating conditions [4], both the switching transitions can take place without violating the output open circuit switching constraint and this will further reduce the overall commutation time. There will be a definite problem at low current level due to offset in the current sensors for which the output current direction might be erroneously indicated. Then the conducting IGBTs may be switched off causing output voltage spike. For example, if S1R is turned off at first by wrongly sensing the current direction as positive, the excessive voltage will occur across the switches.

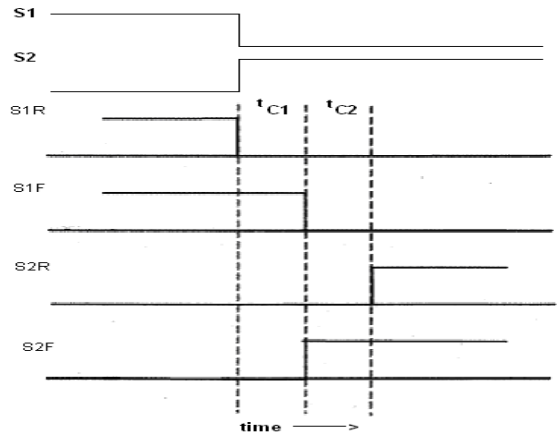

Fig. 6: Three step commutation

The snubbers (R-C) across IGBTs can reduce the voltage spike [4]. For a large capacity IGBTs, resistance for the snubber must be set low to reduce heat dissipation and turn-on losses. For frequent change in the voltages across snubber, losses in snubber itself are quite large. So, it is not suitable for high frequency pulse width modulated matrix converter. However, this spike is reduced by a diode bridge clamp circuit commonly connected between output and input terminals as an extra protection circuit which clamps the output voltage level within the input voltage magnitude[2]

\section{Single step commutation}

In the case of a single-step commutation method, $S_{1 F}, S_{1 R}$ are turned off by reverse bias gate voltage according to the modulation signal and at the same instant of time, $S_{2 F}$ and $S_{2 R}$ get the turned-on gate pulses. The corresponding timing diagram is shown in Fig. 7. The turn-off gate pulses make the outgoing conducting IGBT S1F to be turned off after the turn-off time and make the non-conducting IGBT S1R turned-off quickly (will take less time than the conducting IGBT because of absence of tailing current effect and no storage charge in the drift region). The turn-on gate pulses for the incoming switch cell S2 make the incoming IGBT S2F turned-on within the turn-on time of the IGBT and make the non-conducting IGBT S2R turned-on. There is a possibility of short circuit current for a very short duration when both the IGBT S1F and S1R are in their turning-off and turning -on phase respectively. But this duration is negligibly small because the other incoming IGBT S2F while begins to share the load current make the diode across the IGBT S2R in forward conducting mode. The forward voltage drop across this diode set reverse voltage across the collector emitter of the IGBT S2R making it OFF. Usually the IGBTs are rated to withstand this small duration short circuit current and the input L-C filter reduces the level of this short circuit current. The single-step commutation has advantage of not sacrificing the modulation pulse width for commutation. There is no requirement of current sensors also [8]. 
Vol. 8, Issue 11, November 2021

DOI: $10.17148 /$ IARJSET.2021.81116

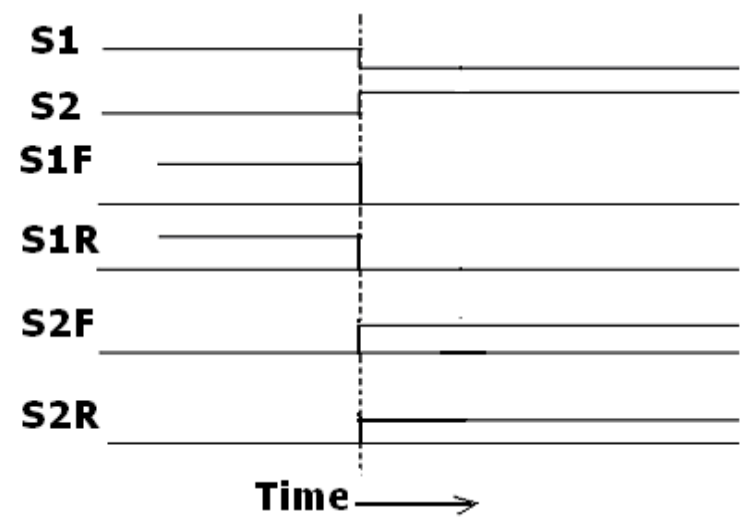

Fig. 7: Single step current commutation

\section{SIMULATION RESULT AND DISCUSSION}

A simulation programs are developed to study in detail the commutation process. The study is carried out with two phase to single phase $(2 \times 1)$ matrix converter. The simulation block diagram consists of different subsystems, measurement blocks and scopes as shown in Fig.8. The subsystem "Two_switch cell" includes the two bidirectional switch configurations using IGBTs and Diode blocks and the logic blocks for determining the current carrying status of the IGBTs. The subsystem "Subsystem6" includes the control logic to distribute gating pulses for the IGBTs. Two ac voltage sources having frequency $50 \mathrm{~Hz}$, phase difference of $90^{\circ}$ and peak magnitude $100 \mathrm{~V}$ are used. The load is a R-L load where $\mathrm{R}=1 \mathrm{ohm}, \mathrm{L}=1 \mathrm{mH}$. Two pulse generators are used to provide modulation signals of frequency $20 \mathrm{kHz}$. The modulation signals are phase displaced by 25 micro-second to maintain the switching constraint.

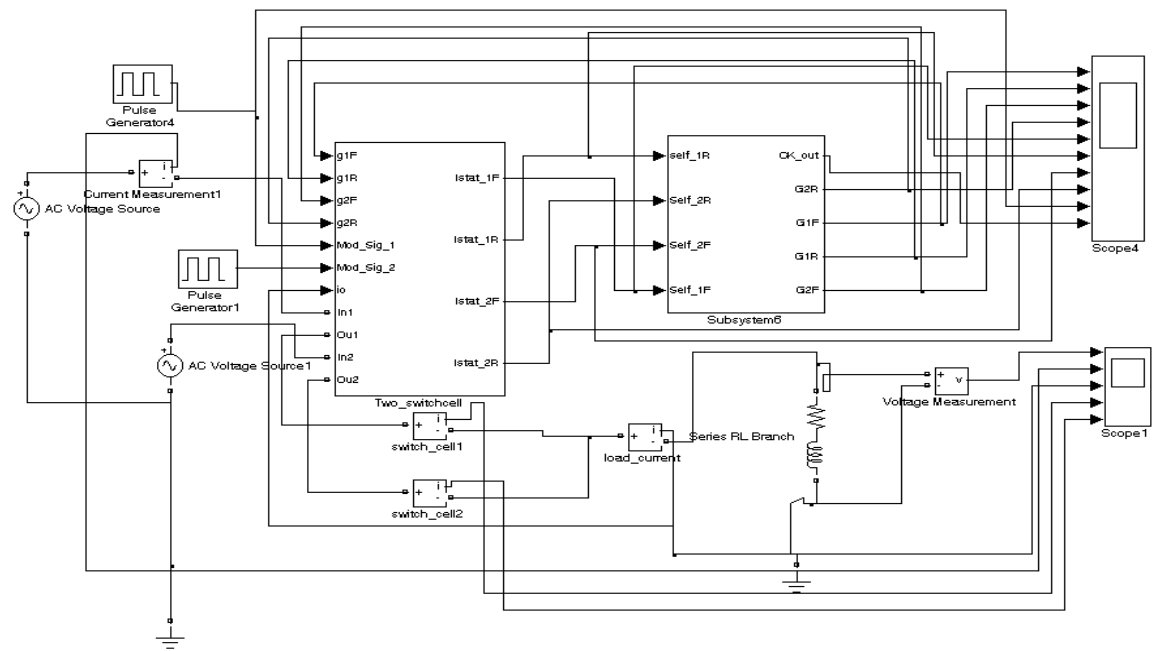

Fig.8. Overall Simulation block diagram

\section{MATLAB/SIMULINK result for four step commutation}

The results are shown in Fig.9, Fig.10 and Fig.11 for output current direction is towards load as shown in Fig.3\&4. As soon as there is a change in modulation signal, the gate pulses of the respective IGBTs are generated to facilitate four step commutation. There is no problem of input short circuit and output open circuit as evident from the simulation result. 
Vol. 8, Issue 11, November 2021

DOI: $10.17148 /$ IARJSET.2021.81116

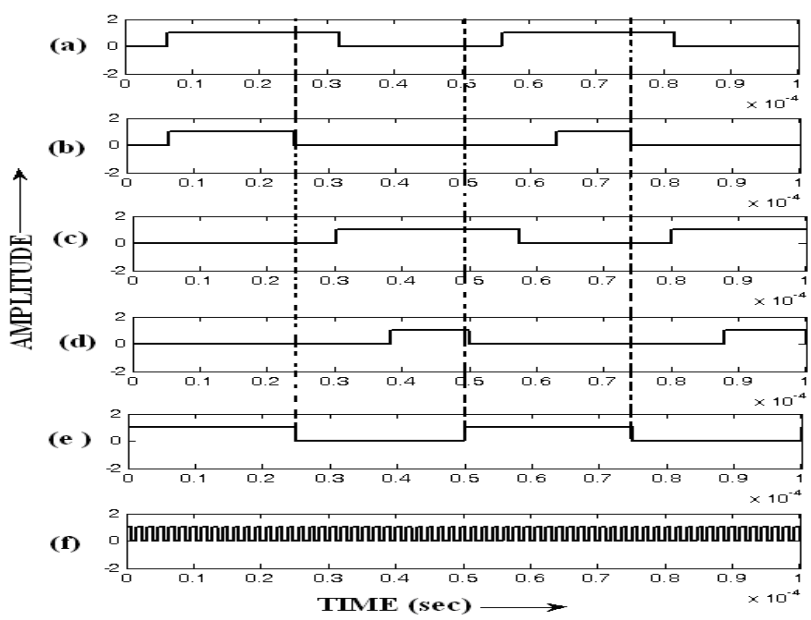

Fig. 9 Four step commutation: Gating pulses (a) gate signal for the outgoing IGBT 1F in switch cell1, (b) gate signal for the outgoing IGBT 1R in switch cell 1, (c) gate signal for the incoming IGBT 2F in switch cell2, (d) gate signal for the incoming IGBT $2 \mathrm{R}$ in switch cell2 and (e) modulation signal for the switch cell 1, (f) clock input for the shift register

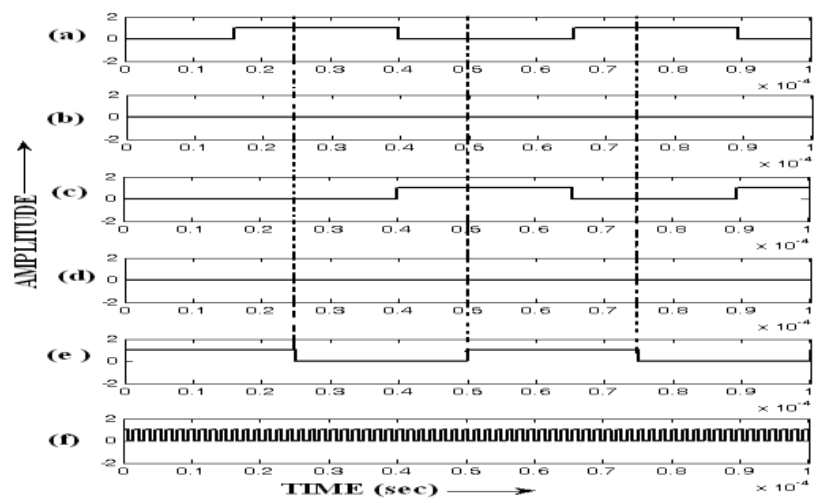

Fig. 10: Four step commutation (current carrying status): (a) status signal of forward conducting IGBT (1F) in switch cell 1, (b) status signal of reverse conducting IGBT (1R) in switch cell 1, (c) status signal of forward conducting IGBT (2F) in switch cell2, (d) status signal of reverse conducting IGBT(2R) in switch cell 2, (e) Modulation signal, (f) clock input signal to the shift register

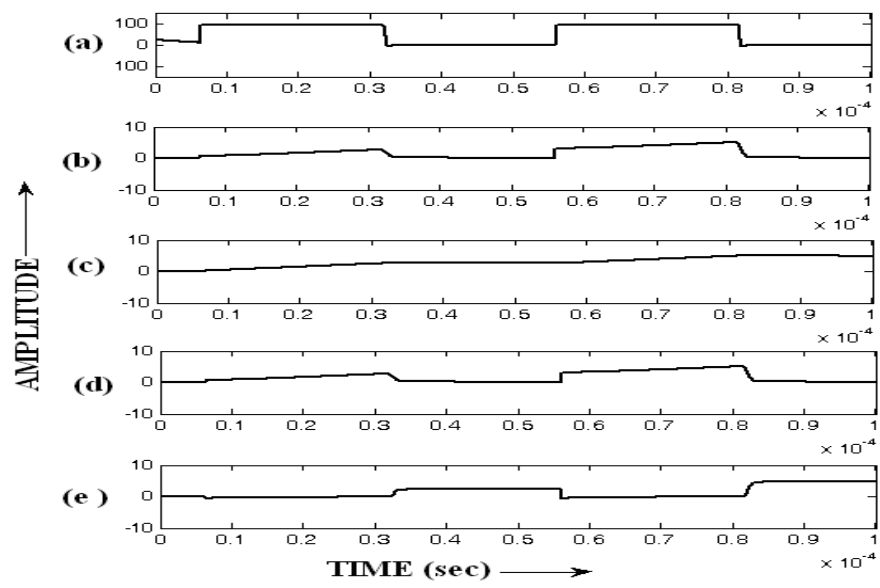

Fig. 11: Four step commutation (voltage and current in different parts): (a) Output load voltage across the R-L branch, (b) current flowing in the input supply line connected to switch cell 1, (c) current flowing in the R-L branch, (d) current flowing through Switch cell 1, (e) current flowing through switch cell 2 


\section{International Advanced Research Journal in Science, Engineering and Technology}

\section{Vol. 8, Issue 11, November 2021}

DOI: $10.17148 /$ IARJSET.2021.81116

\section{MATLAB/SIMULINK result for three step commutation}

The results are shown in Fig.12, Fig.13 and Fig.14 for output current direction towards load as shown in Fig.3.5. As soon as there is a change in modulation signal, the gate pulses of the respective IGBTs are generated to facilitate three step commutation. There is no problem of input short circuit and output open circuit as evident from the simulation result.

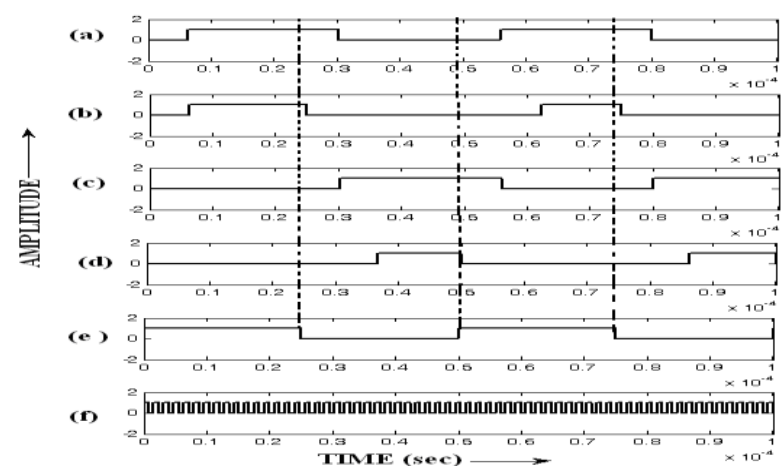

Fig. 12 Three step commutation: Gating pulses (a) gate signal for the outgoing IGBT 1F in switch cell1, (b) gate signal for the outgoing IGBT 1R in switch cell 1, (c) gate signal for the incoming IGBT $2 \mathrm{~F}$ in switch cell2, (d) gate signal for the incoming IGBT 2R in switch cell2 and (e) modulation signal for the switch cell 1, (f) clock input for the shift register

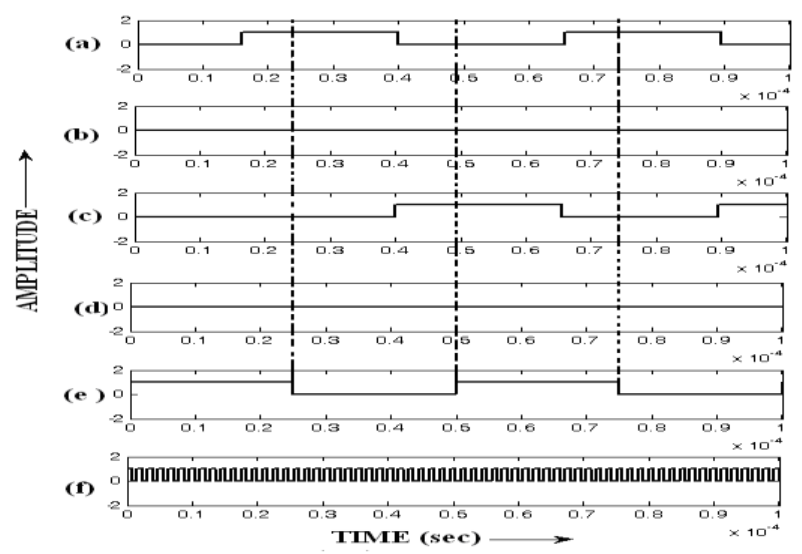

Fig.13: Three step commutation (current carrying status): (a) status signal of forward conducting IGBT (1F) in switch cell 1, (b) status signal of reverse conducting IGBT (1R) in switch cell 1, (c) status signal of forward conducting IGBT (2F) in switch cell2, (d) status signal of reverse conducting IGBT(2R) in switch cell 2, (e) Modulation signal, (f) clock input signal to the shift register

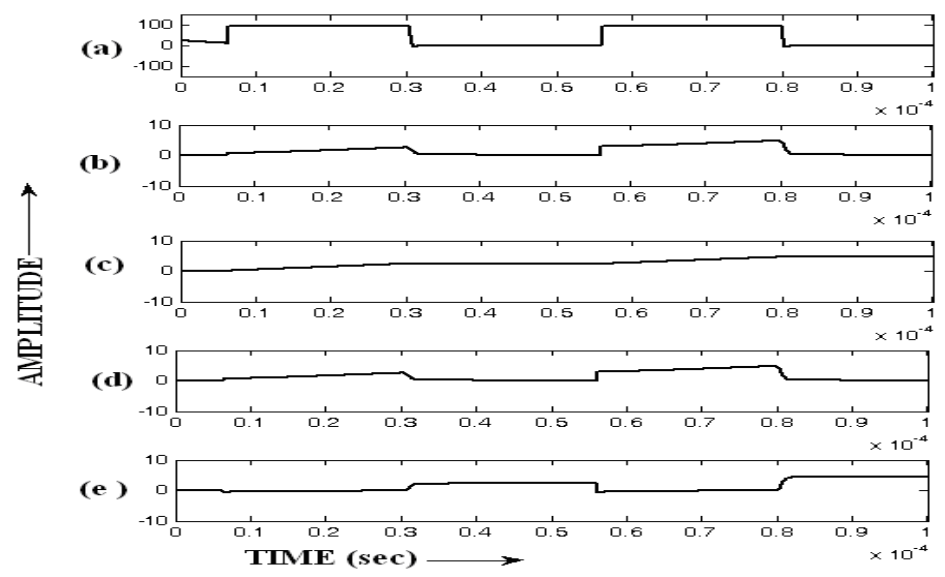

Fig.14: Three step commutation (voltage and current in different parts): (a) Output load voltage across the R-L branch, (b) current flowing in the input supply line connected to switch cell 1, (c) current flowing in the R-L branch, (d) current flowing through Switch cell 1, (e) current flowing through Switch cell 2 


\title{
International Advanced Research Journal in Science, Engineering and Technology
}

\author{
Vol. 8, Issue 11, November 2021
}

DOI: 10.17148/IARJSET.2021.81116

\section{MATLAB/SIMULINK result for single step commutation}

The results are shown in Fig.15, Fig.16 and Fig.17 for output current direction is towards load as shown in Fig.4 . As soon as there is a change in modulation signal, the gate pulses of the respective IGBTs are generated to facilitate single step commutation. This has been observed that commutation will generate voltage spikes in the output. This magnitude of these spikes increases with increase in output current magnitude for a particular value of load inductance. For a very short duration, at the instant of start of commutation, the incoming switch cell takes finite time ( in the order of 100 nanosecond) to turn on. Until the switch is completely turned-on, the load circuit resistance jumps to a high value causing voltage spikes as shown in Fig. 18. However, the voltage spikes are small. Although these voltage spikes can be attenuated to a safe level by using a clamp circuit which allows path for the inductive current for very small duration of time when both the two switch-cells are off at the start of commutation instant..

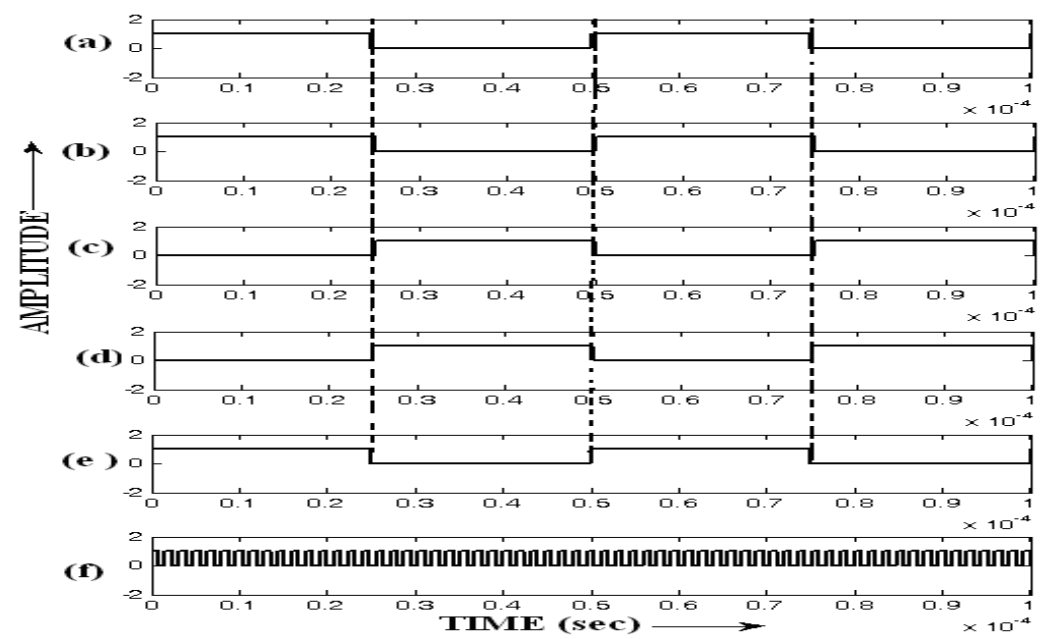

Fig. 15 Single step commutation: Gating pulses (a) gate signal for the outgoing IGBT 1F in switch cell1, (b) gate signal for the outgoing IGBT $1 \mathrm{R}$ in switch cell 1, (c) gate signal for the incoming IGBT 2F in switch cell2, (d) gate signal for the incoming IGBT $2 \mathrm{R}$ in switch cell2 and (e) modulation signal for the switch cell 1, (f) clock input for the shift register

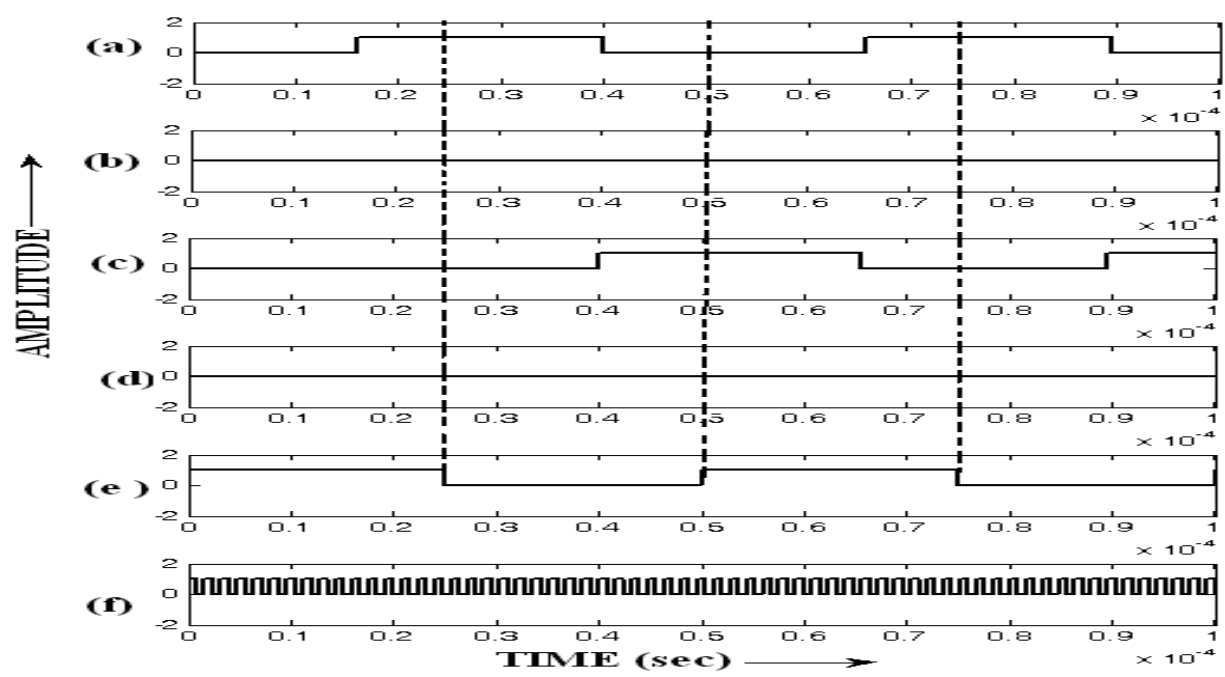

Fig. 16: Single step commutation (current carrying status): (a) status signal of forward conducting IGBT (1F) in switch cell 1, (b) status signal of reverse conducting IGBT (1R) in switch cell 1, (c) status signal of forward conducting IGBT $(2 \mathrm{~F})$ in switch cell2, (d) status signal of reverse conducting IGBT(2R) in switch cell 2, (e) Modulation signal, (f) clock input signal to the shift register 
DOI: 10.17148/IARJSET.2021.81116

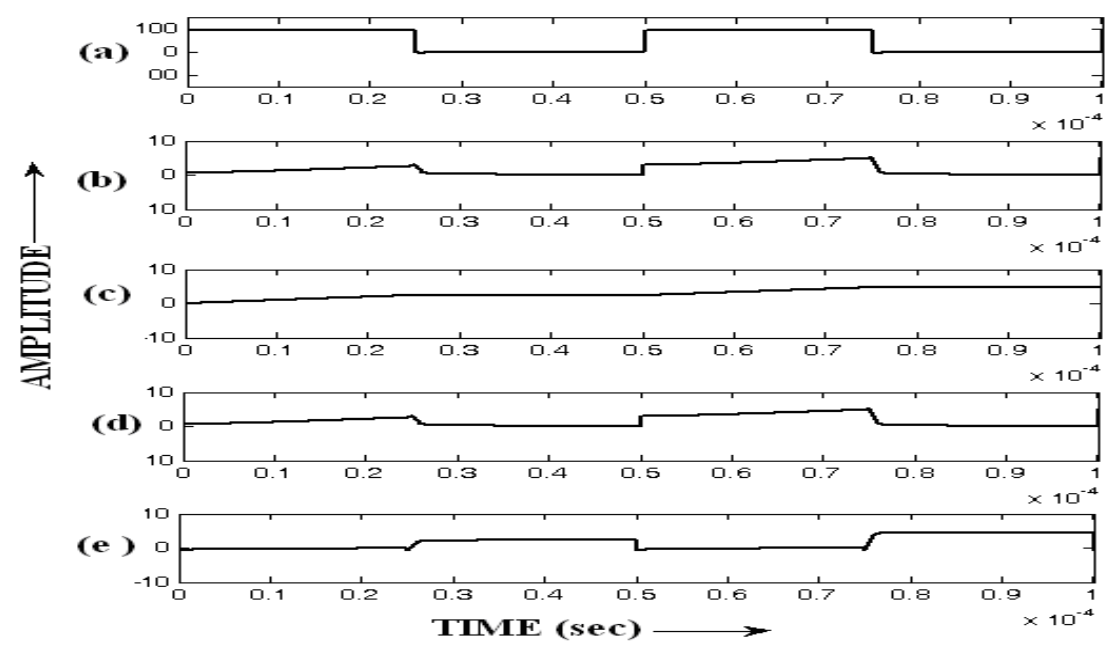

Fig.17: Single step commutation (voltage and current in different parts): (a) Output load voltage across the R-L branch, (b) current flowing in the input supply line connected to switch cell 1, (c) current flowing in the R-L branch, (d) current flowing through Switch cell 1, (e) current flowing through Switch cell 2

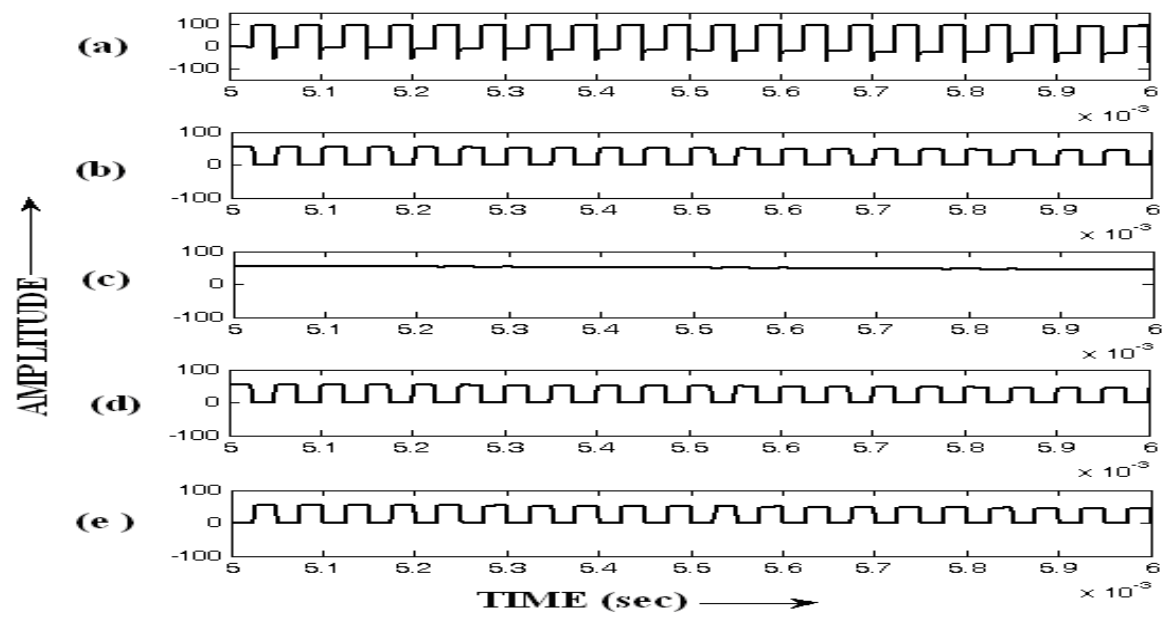

Fig. 18: Single step commutation (voltage and current in different parts) showing voltage spikes at the output: (a) Output load voltage across the R-L branch, (b) current flowing in the input supply line connected to switch cell 1, (c) current flowing in the R-L branch, (d) current flowing through Switch cell 1, (e) current flowing through Switch cell 2

\section{CONCLUSION}

In this paper, a generalized and synchronous implementation of a widely used current commutation strategy in matrix converter through MATLAB simulink is presented. Output Current based different commutation techniques are studied in depth. The reduction of input short circuit current, output voltage overshoot and commutation intervals are the major objectives of the commutation techniques. This has been observed that even with the Four Step commutation technique, input short circuit current can flow. The reason behind is explained. Near zero current the commutation scheme can fail, causing output voltage notches.

\section{REFERENCE}

[1] C. L. Dawes, “A course in Electrical Engineering” Volume II : Alternating Currents

McGraw-Hill Book Company Inc, Kogakusha Co.Ltd, International Student Edition .

[2]P. Wheeler, J. Rodriguez, J. Clare, L. Empringham, A. Weinstein, "Matrix Converters: A Technology Review," IEEE Trans. Ind. Electron., vol.49, pp. 276-289, Apr.2002.

[3]L.Huber and D. Borojevic, , "Space vector modulated three phase to three phase matrix converter with input power factor correction," IEEE Trans Ind. Applicat., vol. 31, pp. 1234-1246, Nov./Dec. 1995.

[4] Ned Mohan, William Robbins and Tore Underland, "Power Electronics converters, Applications and Design ," Media Enhanced third edition , WILEY India edition, 2007

[5] P.wheeler and D.Grant, “Optimisation input filter design and low-loss switching tech. for a practical matrix converter," IEE Proceedings of Electric Power Applications, vol. 144, no. 1, pp 53-60, Jan. 1997 


\title{
International Advanced Research Journal in Science, Engineering and Technology
}

\author{
Vol. 8, Issue 11, November 2021
}

\section{DOI: $10.17148 /$ IARJSET.2021.81116}

[6] P. Wheeler, J. Clare, L. Empringham, “Enhancement of matrix converter Output waveform Quality Using Minimized Commutation Times.” IEEE Trans. Ind. Electron., vol. 51, pp. 240-244,Feb. 2004.

[7] P. Wheeler, J. Clare, L. Empringham, M. Bland, M. Apap, “ Gate Drive level Intelligence and Current Sensing for matrix Converter current Commutation" IEEE Trans. Ind. Electron., vol. 49, pp. 382-389, Apr. 2002.

[8] Anindya Dasgupta, "Dasgupta. A, Mukherjee S, SenGupta M, Syam P, and Chattopadhyay A. K 2006 ' Implementation of Universal Logic System of Generating Commutating Pulses in Matrix Converters using FPGAs', IEEE-ICIT’06, Mumbai, December 2006 (Proceedings in CDROM), pp 1436-1441

[9] M. Munzer, "EconoMac-The first all in one IGBT module for matrix converters," in Proc. Drives and Control Conf., sec. 3, London, U.K., 2001, CD-ROM.

[10] Hao Tian, Yuzhuo Li, Yun Wei Li “Commutation Scheme of Seven-Level Hybrid-Clamped Converters With Suppressed Deadband-Induced Voltage Spikes" IEEE TRANSACTIONS ON INDUSTRIAL ELECTRONICS, VOL. 68, NO. 12, DECEMBER 2021

[11] Amit Kumar Singh, Elango Jeyasankar, Pritam Das, Sanjib Kumar Panda "A Single-Stage Matrix-Based Isolated Three-Phase AC-DC Converter With Novel Current Commutation" IEEE

TRANSACTIONS ON TRANSPORTATION ELECTRIFICATION, VOL. 3, NO. 4, DECEMBER 2017

[12] IEEE Guide for Testing Turn-to-Turn Insulation on Form Wound Stator Coils for Alternating Current Rotating Electrical Machines, IEEE Standard 522-2004, Aug. 2004.

[13] S. Amarir and K. Al-Haddad, "A modeling technique to analyze the impact of inverter supply voltage and cable length on industrial motordrives,” IEEE Trans. Power Electron., vol. 23, no. 2, pp. 753-762, Mar. 2008.

[14] X. Li et al., "Partial discharge characteristics of oil-paper insulation for on-board traction transformers under superposed inter-harmonic AC voltages," IEEE Trans. Dielectr. Elect. Insul., vol. 27, no. 1, pp. $240-248 \quad$ Feb. 2020. [15] G. C. Stone, M. K. W. Stranges, and D. G. Dunn, "Common questions on partial discharge testing: A review of recent developments in IEEE and IEC standards for offline and online testing of motor and generator stator windings," IEEE Ind. Appl. Mag., vol. 22, no. 1, pp. 14-19, Jan./Feb. 2016.

[16] H. Gui et al., "Modeling and mitigation of multiloops related device overvoltage in three-level active neutral point clamped converter," IEEE Trans. Power Electron., vol. 35, no. 8, pp. 7947-7959, Aug. 2020

[17] Á.Mayor,M. Rizo, A. R.Monter, and E. J. Bueno, "Commutation behavior analysis of a dual 3L-ANPC-VSC phase-leg PEBB using 4.5-kV and 1.5kA HV-IGBT modules," IEEE Trans. Power Electron., vol. 34, no. 2, pp. 1125-1141, Feb. 2019

[18] A. F. Moreira, P. M. Santos, T. A. Lipo, and G. Venkataramanan, "Filter networks for long cable drives and their influence on motor voltage distribution and common-mode currents," IEEE Trans. Ind. Electron., vol. 52, no. 2, pp. 515-522, Apr. 2005.

[19] P.W.Wheeler, J. Rodriguez, J. C. Clare, L. Empringham, and A.Weinstein, "Matrix converters: A technology review," IEEE Trans. Ind. Electron., vol. 49, no. 2, pp. 276-288, Apr. 2002.

[20] H. She, H. Lin, B. He, X. Wang, L. Yue, and X. An, "Implementation of voltage-based commutation in space-vector-modulated matrix converter," IEEE Trans. Ind. Electron., vol. 59, no. 1, pp. 154-166, Jan. 2012. 